\title{
The St Andrews Institute for Clinical Research: An early Experiment in Collaboration
}

\author{
JANE MACNAUGHTON*
}

\section{Introduction}

Sir James Mackenzie is revered by general practitioners as the father of general practice-based research. ${ }^{1}$ His name is associated with the University Department of General Practice at Edinburgh and with the Chair at Aberdeen, and he is commemorated in the James Mackenzie lecture given annually at the Royal College of General Practitioners. His fame rests largely on his achievements as a solitary researcher while he worked as a GP in Burnley, a mill town in Lancashire, between 1879 and 1907. It was here that he carried out the pioneering work which contributed to the development of the "new cardiology" at the beginning of the century. ${ }^{2}$ His work in Burnley took him away from general practice and he moved to London to take up private and hospital consulting work to further the impact of his research. He regarded himself, however, as first and foremost a GP, and believed general practice was the proper place for clinical research. ${ }^{3}$ Mackenzie was so committed to this belief that he left London in 1919, an ill man at the age of sixty-six, and

* Jane Macnaughton, MA, MBChB, MRCGP, DRCOG, PhD, Centre for Arts and Humanities in Health and Medicine, University of Durham, 14/15 Old Elvet, Durham, DH1 3HP.

Thanks are due to the Wellcome Trust for granting me a clinical research leave fellowship to carry out this work and to the staff of the Wellcome Unit (now the Centre for the History of Medicine) at the University of Glasgow where I was based. I would like also to thank Malcolm Nicolson, Graham Smith, Robin Downie and Andrew Russell for their comments on earlier drafts of this paper. Marguerite Dupree gave me invaluable support during the time I was at the Wellcome Unit. I have also benefited from discussions with colleagues in the department of General Practice at Glasgow University and from correspondence with Professor John Howie, Professor of General Practice at Edinburgh University.

\footnotetext{
${ }^{1}$ It is an indication of Mackenzie's fame that there have been two biographies of him. The first, The beloved physician (London, John Murray), was written by his admirer, Dr R MacNair Wilson (a physician and journalist with The Times newspaper) and was published in 1926, the
}

year after Mackenzie's death. This book was so popular that it ran to three reprints within seven months. The later, more objective, account was published in 1973 by the second incumbent of the James Mackenzie Chair of Public Health and Social Medicine at the University of St Andrews, Professor Alex Mair: Sir James Mackenzie, MD, 1853-1925, general practitioner, Edinburgh, Churchill Livingstone, 1973.

${ }^{2}$ Christopher Lawrence, 'Moderns and ancients: the "new cardiology" in Britain 1880-1930', in W F Bynum, C Lawrence, and $\mathrm{V}$ Nutton (eds), The emergence of modern cardiology, Medical History, Supplement No. 5 , London, Wellcome Institute for the History of Medicine, 1985, pp. 1-33, p. 16. This paper gives an account of Mackenzie's significance to the development of cardiology. Further accounts are to be found in the biographies above.

${ }^{3}$ Ibid., pp. 15-16. Mackenzie made frequent reference to this belief in his writings, such as his book The future of medicine, London, Henry Frowde, Hodder \& Stoughton, 1919, p. 45. His view was that clinical specialism was retarding the advance of medicine by concentrating research on the end stages of disease, when it was too late to prevent death or serious illness. 


\section{Jane Macnaughton}

established the Institute for Clinical Research in St Andrews. The Institute involved the GPs of St Andrews working together in collaborative research under Mackenzie's leadership.

This paper will reassess Mackenzie's significance for the development of general practice-based research and for general practice as a specialty by examining this project of his later years. The Institute was an innovative venture at this time. Clinical research was still very much an individualistic activity and, as fewer GPs were doing research in the form of MD degrees, individual GPs were generally less likely to be involved in research. ${ }^{4}$ The St Andrews Institute can be seen as an attempt by Mackenzie to set up the kind of research structure for GPs that was beginning to emerge in the London teaching hospitals: specialist clinicians associated with university scientists. Mackenzie's model did not continue and there was a long gap before university departments of general practice emerged (the first professor of general practice was Richard Scott appointed in 1963 in Edinburgh). ${ }^{5}$

The first section of the paper will fill in some background of Mackenzie's life and work before he came to St Andrews in order to give some understanding of his motivation and experience, and of his early fame. The second section will describe the Institute, its members, what it set out to do, and, particularly, how it was funded; and the final section will discuss why Mackenzie did not succeed in establishing the Institute on a permanent basis and assess its significance in the history of GP research.

\section{Mackenzie's Earlier Years and Research Ideas}

Mackenzie was born and bought up on Pictstonhill Farm in Perthshire, the second son of a family of seven. His schooling did not leave him with a very high regard for his own intellect and when he left Perth Academy at the age of fourteen he was apprenticed to a chemist. During his five years apprenticeship he took to reading widely and became convinced that he had the ability to go to university, and he went on to study medicine at Edinburgh. Despite some successes there, particularly in the clinical years of his training, his early schooling experiences left him with a feeling of inferiority. He would have preferred a career in some "branch of medicine concerned in research" but, as he later said, "I quite clearly recognised that I was only suited for what is considered the lowest place in the profession", in other words, general practice. ${ }^{6}$

He joined the practice of Dr John Brown and Dr Henry Briggs in Burnley, having

\footnotetext{
${ }^{4}$ Christopher Lawrence gives a general account of the development of clinical research in the UK and the USA in 'Clinical research', in $\mathrm{J}$ Krige and D Pestre (eds), Science in the 20th century, Amsterdam, Harwood Academic, 1997, pp. 439-59, pp. 444-5. Anne Digby, in her recent book on the history of general practice, The evolution of British general practice, Oxford
}

University Press, 1999, shows the decline in MDs amongst GPs (p. 218).

${ }^{5}$ John Howie, 'Research in general practice: perspectives and themes', in I Loudon, J Horder, $\mathrm{C}$ Webster (eds), General practice under the National Health Service, London, Clarendon Press, 1998, pp. 146-64, p. 151.

${ }^{6}$ Mair, op. cit., note 1 above, p. 36. 


\section{The St Andrews Institute for Clinical Research}

known and admired Brown at university. ${ }^{7}$ He stayed in Burnley for most of his working life (twenty-eight years) and here started the research which was to lead to his acclaimed work in heart disease. He already had an interest in research work before going to Burnley but cannot have held out much hope of pursuing this in a busy general practice. He soon found, however, that he was unable to do his job without doing research because his medical training had not equipped him for the job he had set out to do:

I had not been long in the practice when I discovered how defective was my knowledge. I left college under the impression that every patient's complaint could be diagnosed. For a long time I strove to make a diagnosis and assiduously studied my lectures and my textbooks without avail ... For some years I thought that this inability to diagnose my patients' complaints was due to personal defects, but gradually ... I came to realise that the kind of information I wanted did not exist. ${ }^{8}$

Mackenzie's problem was that there was no systematically obtained knowledge available in published form about the problems presenting in general practice. Medical research focused on the end stages of disease - on what could be dissected on the anatomy table or examined on the pathology bench. Mackenzie wanted to know in what ways the early symptoms and signs of disease that presented to him as a GP were related to these end stages. It was his modern view that the main aim of clinical research was the prevention of disease. This, he argued, could be achieved only if we understood the significance of early symptoms and signs.

This early disillusionment with his medical training strongly influenced Mackenzie's approach to research. He wanted to give patients a correct prognosis by being able to distinguish insignificant symptoms and signs from serious and life-threatening ones and his method was one of careful and methodical recording of his own patients' illnesses. Mackenzie's focus was, therefore, entirely clinical but his "thinking was physiological". ${ }^{9}$ His case recording was filtered through extensive reading in experimental physiology and he was in correspondence during his Burnley years with physiologists like Charles Sherrington (later, a Nobel prize winner) and Charles Roy, professor of the pathological laboratory at Cambridge University. ${ }^{10}$

His work focused upon the problem of the heart's irregular action and he invented an instrument called the "ink polygraph" which made tracings of the action of the separate chambers of the heart from rubber tubes that were connected to the jugular venous pulse in the neck, the radial pulse and the apex beat on the chest. ${ }^{11}$ His ability to record the motion of the heart muscle at the bedside, and to relate this to the patient's symptoms, enabled Mackenzie to distinguish pathological irregularities,

\footnotetext{
${ }^{7}$ Ibid., p. 37. Dr John Brown had been Lister's demonstrator and dresser at Edinburgh Royal Infirmary and persuaded Mackenzie to apply for a residency at the Royal before he entered general practice.

${ }^{8}$ Edinburgh University library special collections department (EUL), MS Gen. 1980, box 6: Sir James Mackenzie, 'Personal experiences'. Edinburgh University Library
}

\author{
contains 10 boxes of miscellaneous material \\ relating to Mackenzie. This material was given to \\ the library by Professor Mair after he had \\ completed his biography. \\ ${ }^{9}$ Lawrence, op. cit., note 2 above, p. 14. \\ ${ }^{10}$ Mair, op. cit., note 1 above, p. 96. \\ ${ }^{11} \mathrm{~T}$ Osborne, 'James Mackenzie, general \\ practitioner', Sociology of Health and Illness, \\ 1993, 15: 525-46, p. 527.
}




\section{Jane Macnaughton}

such as atrial fibrillation, from benign ones, such as what would now be called sinus arrythmia, which is, in fact, a reflection of youthful good health. ${ }^{12}$ He went so far on one occasion as to suggest that the discovery of the stethoscope had done as much harm as it had done good as so many people with healthily functioning hearts had been condemned to lives of invalidism because they had benign murmurs. ${ }^{13}$ These distinctions were important prognostically for patients, but Mackenzie's work also made a major contribution to the change in the way in which the heart was conceptualized-from a static anatomical specimen to a functioning physiological organ.

In 1902 he published his first book based on his work with the polygraph, entitled The study of the pulse. ${ }^{14}$ This was reviewed in glowing terms by Professor Clifford Allbutt: "But today, from the Galilee of Burnley in Lancashire, comes a new teacher to prove to us that our content was shallow enough; and in an important work he has lifted the whole subject into a fresh light and into a larger aspect." 15 This book paved the way to further association with others who were working in the field, such as Sir Arthur Keith and Professor Karl Wenckebach. In 1907 Mackenzie moved south to London to gain greater recognition for his work. ${ }^{16}$ He established a lucrative private practice in Harley Street and was appointed Lecturer in Cardiac Research at the London Hospital in 1911 and consultant there (to the disgust of senior staff) in $1913 .{ }^{17} \mathrm{He}$ was briefly "Physician in charge of the Department for Cardiac Research", with fifteen beds at his disposal and an assistant in the person of Dr (later Sir) John Parkinson. ${ }^{18}$ When the war came, Mackenzie gave up his beds for the care of the wounded, but his reputation and fame were secure and honours soon followed. He was elected Fellow of the Royal Society in March 1915, and knighted in June of that year.

By the time, then, that Mackenzie moved to St Andrews to set up the Institute for Clinical Research, he was firmly established as an important figure in medicine, known and respected by powerful men such as Sir Walter Fletcher, Secretary of the Medical Research Council, and Sir Robert Morant, Chairman of the National Health Insurance Commission. ${ }^{19}$ More significantly for his success in St Andrews, he would have been revered by GPs around the country as a rare example of a GP who had risen to become a leading consultant. It is reasonable, therefore, to accept the account of Mackenzie's biographer, MacNair Wilson, of the response of the St Andrews GPs to his arrival in their midst:

\footnotetext{
${ }^{12}$ Lawrence, op. cit., note 2 above, p. 15.

${ }^{13}$ Mair, op. cit., note 1 above, p. 242.

${ }^{14}$ James Mackenzie, The study of the pulse: arterial, venous and hepatic, and of the movements of the heart, Edinburgh and London, Young $\mathbf{J}$ Pentland, 1902.

${ }^{15}$ Book review in Br. med. J., 1902, ii: 250-1, p. 250. Mair (op. cit., note 1 above, p. 181) confirms that it was Allbutt who wrote the review.

${ }^{16}$ It was not until his second book, Diseases of the heart, was published in 1908 (London, Henry
}

Frowde, Hodder \& Stoughton) that Mackenzie's reputation in London was secure enough for him to make money in his private practice.

${ }^{17}$ Lawrence, op. cit., note 2 above, p. 29.

${ }^{18}$ Mair, op. cit., note 1 above, p. 258-9.

${ }^{19}$ Mackenzie's relationship with Fletcher will be described later in this paper. For his dealings with Morant over record-keeping for GPs, see Frank Honigsbaum's account in The division in British medicine: a history of the separation of general practice from hospital care, 1911-1968, London, Kogan Page, 1979, pp. 94-100. 


\section{The St Andrews Institute for Clinical Research}

Some of these doctors have told me of the thrill of wonder with which they heard him. Here, on their doorsteps, stood the most renowned physician of his age, a man whose name had become almost a legend, asking to be permitted to undertake, on their behalf, a little of the burden of family practice in a small Scottish town. It took their breaths away. ${ }^{20}$

\section{The Institute and its Activities}

Despite the years in London, Mackenzie's view of clinical research remained rooted in his experiences in general practice and influenced by the need to solve the problems of the ordinary GP. He revealed his motivation in a letter to a young cousin written the day before he died:

When I left London I dared not tell anyone the real reason for my leaving, for it would have been looked on as a piece of folly. For years I had been gradually becoming convinced that the whole tendency of research was on the wrong lines; it was devoid of fundamental principles, was haphazard, and could not supply the kind of knowledge which would enable us to solve medical problems. ${ }^{21}$

It is remarkable that he was prepared to uproot himself and start a new project at this late stage in his life (he was sixty-six when he established the Institute and was suffering from angina) and it has been suggested that he chose to go to St Andrews more for retirement and the golfing facilities than the research opportunities: he was a keen golfer all his life. ${ }^{22}$ However, when we consider the extensive aims that the Institute set for itself, it is difficult to come to this conclusion.

On his arrival in St Andrews in 1918, Mackenzie was appointed consulting physician to the St Andrews Cottage Hospital and through this met the GPs of the town. The following year, having gained their support, he established his Institute for Clinical Research. The first annual report of the Institute reveals the ambitious list of aims and plans. ${ }^{23}$ The major ones were: firstly, to investigate disease before it led to pathological changes, with the hope of providing information which would lead to earlier diagnosis of a condition. Secondly, the GPs intended to investigate the minor symptoms and signs which presented in general practice in order to elucidate their mechanism of production and their significance for the patient. Thirdly, the Institute doctors were to keep a continuous record of all cases they saw, including details of the patients' living conditions, dietary and smoking habits and employment, so that research could be carried out into the relationship between environmental factors and disease. Fourthly, special attention was to be paid to the investigation and recording of the health and illnesses of children, with particular emphasis on "the predisposing causes of consumption". From the outset, the Medical

\footnotetext{
${ }^{20}$ MacNair Wilson, op. cit., note 1 above, p. 275.

${ }_{21}$ 'Sir James Mackenzie's last letter', The Times, 11 Feb. 1925.

${ }^{22}$ Mair, op. cit., note 1 above, p. 295.

${ }^{23}$ EUL MS Gen. 1980, box 8: 'First Annual Report of the St Andrews Institute for Clinical
}

\footnotetext{
Research', Oct. 1920. In addition to the following aims, the Institute intended to provide postgraduate courses for training GPs in the methods of research which they could employ in their own practices.
} 


\section{Jane Macnaughton}

Research Council funded a researcher, Dr Andrew Rowand, who was in charge of what became known as the "Children's Department" at the Institute. ${ }^{24}$

A council of management was created, which consisted of a number of local businessmen who supported the Institute financially, and the Principal of St Andrews University. Mackenzie himself was appointed Director. There were initially five GP medical staff and Percy Herring, professor of physiology, and David Waterston, professor of anatomy at the University were involved to help. A building was leased and later bought at the Scores in St Andrews, which was equipped with consulting rooms, a library, X-ray and laboratory facilities and a room for secretarial staff.

The plan was that the GPs would spend at least part of each day at the Institute examining and recording details of patients they had selected out of their own panel or private lists, and the cases would be the subject of weekly discussions by the staff. There would be the opportunity for special investigations to be carried out if required at the laboratories of the Institute. ${ }^{25}$ The GPs' records and progress notes of the cases would be retained at the Institute "so that a continuous record of each patient may be correlated with the eventual outcome of the illness". ${ }^{26}$ Some time was spent in the first two years of the Institute's existence getting the method of case recording right so that cross-referencing to other cases would be facilitated. ${ }^{27}$

Mackenzie viewed the Institute's work as a long-term project lasting at least thirty years as the value of the records would not become clear until signs of definable disease became manifest in the patients under study. ${ }^{28} \mathrm{He}$ had chosen St Andrews because it presented a stable and manageable population of around 8,000 patients, and the Institute had access to this population because he had managed to involve all the GPs who were working in the town. ${ }^{29}$ The Institute also had access to the expertise of the University, and Waterston and Herring were active in the work during the years of Mackenzie's directorship.

The plan for the Institute had much in common with the reorganization of the panel doctor system proposed by the Dawson Report in $1920 .{ }^{30}$ Lord Dawson was a prominent physician who, as chairman of the Medical Consultative Council, was given the task by the Ministry of Health of producing proposals to reform the National Health Insurance system. ${ }^{31}$ Dawson envisaged that GPs would have access to small "primary" health centres where they would be able to see patients as well

\footnotetext{
${ }^{24}$ An account of the importance of research into tuberculosis for the MRC is given in Linda Bryder, 'Tuberculosis and the MRC', in Joan Austoker and Linda Bryder (eds), Historical perspectives on the role of the $M R C$, Oxford University Press, 1989, pp. 1-21.

${ }^{25}$ Public Record Office (PRO) FD 1/571, J Mackenzie to W Fletcher, 'Memorandum on some of the medical aspects of work under the National Health Insurance Act', from the section entitled, 'Methods pursued by the St Andrews Institute for Clinical Research'.

${ }^{26}$ 'First Annual Report', op. cit., note 23 above, Director's report.

${ }^{27}$ PRO FD 1/571, 'Memorandum upon medical records presented to the Medical
}

\author{
Research Council', sent to Fletcher by \\ Mackenzie, 2 Feb. 1922. \\ ${ }^{28}$ EUL MS Gen. 1980, box 4: 'Papers from \\ the weekly staff meetings [of the Institute]', No. 1, \\ May 1933, contains an article by G M Fyfe (a \\ member of the medical staff) with the comment, \\ "Mackenzie reckoned that thirty years would \\ elapse before the work bore fruit". \\ 29 'First Annual Report', 'Report by the \\ Director', op. cit., note 23 above. \\ ${ }^{30}$ Ministry of Health Consultative Council on \\ Medical and Allied Services, Interim report on the \\ future provision of medical and allied services \\ (Dawson Report), HMSO, 1920, Cmd. (Great \\ Britain. Parliament) 693. \\ ${ }^{31}$ Honigsbaum, op. cit., note 19 above, p. 64.
}




\section{The St Andrews Institute for Clinical Research}

as make use of diagnostic facilities, such as laboratories and X-rays. Such a change would mean that GPs would increasingly work in group practices and that this would involve greater opportunities for intellectual and educational exchange. ${ }^{32}$ The GPs working at the Institute were to have access to such facilities and Mackenzie emphasized the importance of the intellectual stimulus that group practice would involve. ${ }^{33}$ However, the Institute's creation was not expressly for the purpose of clinical care but for research and here it differed from the health centres planned under Dawson's proposed reforms. This point is well illustrated by the fact that in 1919 Mackenzie declined the offer to chair a committee to look at the keeping of records in panel practice and to make recommendations for improvements. This was because he did not agree with the view that improved record-keeping would lead to better patient care. He did, however, contribute to the eventual report of that committee (the Rolleston Report) by constructing a memorandum on the work of the Institute. ${ }^{34}$ This document expresses his view that improvements in therapy were a long way off because of the defects in current medical knowledge:

The incompleteness of medical knowledge at the present time is clearly shown by the fact that a very large number of patients who consult their doctor ... do not suffer from any disease referable to the current classification, or one which can be detected by physical signs ... The cause of such symptoms is frequently unknown, and therefore cannot be rationally treated. $^{35}$

Rational treatment would not be possible, in Mackenzie's view, until research was carried out of the kind he was initiating at St Andrews where the patient's illness was followed and recorded over a long period from its earliest signs and symptoms to the point where clear pathology was detectable.

Although Mackenzie placed the emphasis in terms of record-keeping in the Institute on its research purpose, his interest was, therefore, not an epidemiological one-he was not concerned with disease in populations. He was concerned with the mechanism of disease in the individual and how the early symptoms and signs of disease were related to developing pathology. He was fascinated by physiology and by explaining the mechanisms whereby disease revealed itself in the form of symptoms and signs. During the first five years of the Institute, therefore, as the dogged collection of case records continued, the Tuesday staff meetings were spent discussing these mechanisms, and the results of these discussions formed the basis of most of the early publications of the Institute. Notable amongst these was The basis of vital activity published in 1926 (after Mackenzie's death), which presents his theory that the symptoms of disease are the result of disrupted reflexes. ${ }^{36}$ His account of this theory reveals why physiologists might have found his use of the term "reflex" confusing:

\footnotetext{
${ }^{32}$ Dawson Report, op. cit., note 30 above, p.14, para. 50 .

${ }^{33}$ PRO FD 1/571, 'Memorandum on some of the medical aspects of work under the National Health Insurance Act', by Sir James Mackenzie and the Staff of the St Andrews Institute for Clinical Research, 1919, p. 2.

${ }^{34}$ Ibid.
}

\footnotetext{
${ }^{35}$ Ibid., p. 2.

${ }^{36}$ Sir James Mackenzie, The basis of vital activity, London, Faber and Gwyer, 1926. This work was significantly subtitled: being a review of five years' work at the St Andrews Institute for Clinical Research, indicating the importance of this side of the work in Mackenzie's mind.
} 


\section{Jane Macnaughton}

The whole economy of the body is built up of a system of organs whose activities depend on reflexes. A flood of stimuli is continually being poured into the system through the skin and special senses, and each stimulus produces a definite reflex on some part of the body. In the deeper tissues of the body stimuli are continually arising and being sent to different organs, which respond by some modification of their activity.

The sources of stimulation, therefore, arise in every part of the body. Organs that at one time are the source of stimulation become at other times the effectors ... The interplay of these reflexes results in the harmonious action of the organs of the body which we recognize as "health". The disturbance of one or more of these reflexes results in a disharmony which we recognize as the symptoms of disease. ${ }^{37}$

Mackenzie and his co-workers in St Andrews, including Herring, the professor of physiology, acknowledged that their use of the term "reflex" was wider and vaguer than that in use at the time but this did not prevent his work being subject to ridicule when it reached physiological circles. ${ }^{38}$ Henry Head was sent a copy of Mackenzie's theory and noted that "the word 'reflex' plays the part of King Charles' head; it is used to cover all sorts of phenomena, and crops up in unexpected places". ${ }^{39}$ Fletcher's response was only slightly less scathing:

I have always held that, apart from M's loose thinking and talking - the results no doubt of want of education-some valuable results may come from St Andrews, if they will patiently trace out the life-histories of a sufficient number of children and young persons in that place. ${ }^{40}$

Mackenzie was invited to take part in a discussion on reflexes at the British Association for the Advancement of Science in Edinburgh in 1921 but his paper was omitted—much to Mackenzie's disgust—because neither Head nor Sherrington could attend the discussion. ${ }^{41}$ There is no evidence that Mackenzie was invited to air his theory at any other high profile scientific meetings.

\section{Mackenzie's GP Co-Workers}

It is a remarkable fact that although Mackenzie was not personally acquainted with the GPs of St Andrews before he arrived and started his consultancy in the local cottage hospital, the first annual report of the Institute records that all the GPs of the town were "interested" in the work of the Institute "and a number devote a considerable part of their day to it". ${ }^{42}$ It is also remarkable that these GPs, used to working individually, came together at the Institute to share ideas and theories about the illnesses of their patients. Although it was primarily a research organization, the Institute must have had something of the feel of the kind of primary health

\footnotetext{
${ }^{37}$ Sir James Mackenzie (ed.), Reports of the $S t$ Andrews Institute for Clinical Research, vol. 1, London, Henry Frowde and Hodder \& Stoughton, 1922, pp. 57-8. The Institute published three volumes of reports in book form, in 1922, 1924 and in 1926. In his article in vol. 1, Mackenzie gives an account of the development of his "theory of disturbed reflexes".

${ }^{38}$ For the work of Charles Sherrington (and Henry Head) on the reflex see Ragnar Granit,
}

Charles Scott Sherrington: an appraisal, London, Nelson, 1966, pp. 47-83.

${ }^{39}$ PRO FD 1/571, H Head to W Fletcher, 19 July 1921 .

${ }^{40}$ Ibid., W Fletcher to H Head, 20 July 1921. 1921.

${ }^{41}$ Ibid., J Mackenzie to W Fletcher, 27 June

42 'First Annual Report', op. cit., note 23 above. 


\section{The St Andrews Institute for Clinical Research}

centres Dawson envisaged when several GPs were examining, carrying out tests and recording case records of their patients in the consulting rooms.

Only two of the seven GPs working at the Institute in the early years of the 1920s had MDs, indicating some previous interest and involvement in research. Despite this, Mackenzie wrote to Walter Fletcher in 1921 that "some of them are the very ablest investigators that it has ever been my fortune to come across". ${ }^{43}$ Fletcher was not so sanguine about the GPs and suggested to Mackenzie that he had "erred ... in supposing that any, or many, practitioners (under present conditions) can do this work". ${ }^{44}$ Fletcher did not think GPs were capable of high quality scientific research and he was being diplomatic with Mackenzie in suggesting that it was just their conditions of work that prevented them. It was correct, however, that the major difficulty Mackenzie faced in getting the GPs involved in research was in paying them. At the outset, the GPs received salaries of $£ 200$ per year for their work. Mackenzie was well aware of the financial pressures they were under: "we can only expect good work if they are free from financial worry", he commented in the first annual report. One of the GPs in particular was on Mackenzie's conscience-this was Dr James Orr, who got so interested in the work of the Institute that he was paid $£ 500$ to take on a partner to help service his practice, which was worth $£ 1800$ per year, so that Orr could work in the Institute part-time. ${ }^{45}$ This difficulty became a crisis when the salaries paid to the medical staff were withdrawn for lack of funding in 1925.

\section{Funding of the Institute}

Initial funding of the Institute came from four main sources: private donations and subscriptions, the Carnegie Trust, the Medical Research Council (MRC) and Mackenzie's own personal wealth. ${ }^{46}$ The private support came from wealthy patients Mackenzie had treated while in London-notably Lord Northcliffe, the press magnate, who gave $£ 500$ per year for the first five years-and from interested wealthy local people. The Carnegie Trust gave $£ 1000$ per year for five years and this was administered through the University of St Andrews. The purpose of the grant was to provide for lecturers in bacteriology and in clinical chemistry, both of whom would work at the Institute but who would have access to University facilities. ${ }^{47}$ There was a residue from this grant of $£ 200$, which was paid to the Institute for general purposes.

Mackenzie was, however, concerned about the future support of the Institute from the time of its foundation, and was keen to establish it on a sound footing before

\footnotetext{
${ }^{43}$ PRO FD 1/571, J Mackenzie to W Fletcher, 27 June 1921. 1920.

${ }^{44}$ Ibid., W Fletcher to J Mackenzie, 29 April

${ }^{45}$ PRO FD 1/572, J Mackenzie to W Fletcher, 18 Feb. 1924.

${ }^{46}$ Ibid. This letter, written when Mackenzie was becoming increasingly "crippled" by his angina, reveals how much of his own financial
}

\author{
resources Mackenzie was devoting to the \\ Institute. He had intended to give up private \\ consulting work when he founded the Institute \\ but returned to it (despite his health problems) to \\ help with funding. \\ ${ }^{47}$ EUL MS Gen. 1980, box 1: excerpts from \\ minutes of meetings of University of St Andrews \\ Court regarding the administration of the \\ Carnegie grant.
}




\section{Jane Macnaughton}

he had to give up directing its work. In 1922 he was talking in terms of needing $£ 100,000$ "to put the Institute on a really sound basis" but he never acquired this amount of capital. ${ }^{48}$ His major achievement was in securing the interest and backing of the MRC, which gave the Institute a total grant of $£ 1300$ in $1922 .{ }^{49} £ 400$ of this was for the full-time salary of Dr Rowand, and $£ 200$ each went to Professors Waterston and Herring as recompense for the time they were giving to the Institute. The remaining $£ 500$ went specifically towards the maintenance of the records.

Mackenzie must have been pleased with this support, although it was less than he had asked for and specifically did not help him with the problem of paying the GPs. ${ }^{50}$ Because of his health and his age, he was well aware that he had not many years of working life left, and in his correspondence with Walter Fletcher in the early 1920s he was continuously urging Fletcher to consider the possibility that the MRC might eventually take over the running and direction of the Institute. ${ }^{51}$ As he wrote in 1921, "I have always felt that your Council were the proper people for this work". ${ }^{52}$ However, it was not clear that the MRC saw themselves in this light, and the grant was given, partly as a personal tribute to Mackenzie, partly because Fletcher thought that some interesting work might come out of the records themselves, but largely as a result of the support of Noel Paton, who was professor of physiology at Glasgow University and was at this time Chairman of the Scottish Committee investigating child health. ${ }^{53}$ Paton visited the Institute on behalf of the MRC in 1921 and his report was enthusiastic. ${ }^{54} \mathrm{He}$ recommended it to Fletcher saying, "It is one of those schemes which in my opinion it is the duty of the Medical Research Council to foster." "55 But Paton also acknowledged that the Institute would succeed only with someone like Mackenzie at the helm.

By 1924, Mackenzie's health had deteriorated to such an extent that he had to move back to the softer climate of London where he died of a myocardial infarction in January 1925. The Carnegie grant lapsed in this same year and the Council of the Institute were forced to withdraw salaries to the GPs. ${ }^{56}$ An appeal was made to the MRC to take over the direction and support of the Institute but this was turned

\footnotetext{
${ }^{48}$ EUL MS Gen. 1980, box 1: J Mackenzie to Mr Mitchell, 22 Dec. 1922.

${ }^{49}$ PRO FD $1 / 572$, W Fletcher to J Mackenzie, 13 May 1922: a letter containing details of this grant.

${ }^{50}$ PRO FD 1/571, J Mackenzie to W Fletcher, 6 March 1922. Mackenzie's original request for a grant was for a total of $£ 2300$, and included a request for the part-time salaries of five GPs.

${ }^{51}$ Ibid., J Mackenzie to W Fletcher, 29 March 1920. 1921.

${ }^{52}$ Ibid., J Mackenzie to W Fletcher, 27 June

${ }^{53}$ Ibid., W Fletcher to N Paton, 8 Dec. 1921. Paton and his colleagues published a report on child health and nutrition in 1926: D Noel Paton and Leonard Findlay, Child life investigationspoverty, nutrition and growth: studies of child life
}

in cities and rural districts of Scotland, London, HMSO, 1926.

${ }^{54}$ Paton, unlike many of the London based clinical scientists, would have shared Mackenzie's view of the importance of close working relationships with clinicians for the success of clinical research. See David Smith and Malcolm Nicolson, "The "Glasgow School" of Paton, Findlay and Cathcart: conservative thought in chemical physiology, nutrition and public health', Soc. Stud. Sci., 1989, 19: 195-238, pp. 206-7.

${ }^{55}$ PRO FD 1/571, N Paton to W Fletcher, 8 Feb. 1922.

${ }^{56}$ St Andrews University Library Special Collections George Steedman Riddell Collection, MS 380009 box 3/3, Annual reports of the Clinical Institute, St Andrews Fife, 3 vols, 'Sixth Annual Report', 1925. 


\section{The St Andrews Institute for Clinical Research}

down. By 1927 the view of the MRC was that: "The Institute is playing a useful part in the public health and general medical work of the town, but that is not our affair. As regards research, little is being done now beyond the collection of records." 57

\section{The Institute before and after Mackenzie's Death}

The conclusion of the MRC was largely correct, and the change in activities of the Institute after Mackenzie's departure and death is reflected in the content of the annual reports. In the first five years of the Institute, while Mackenzie was still Director, the reports give a detailed account of the numbers of records kept-both of adults and children-and of how the staff were learning more from the records about the relationship between environment and the health of the children. There are accounts of the development of the theory of disturbed reflexes and its relationship to the symptoms they were recording. After Mackenzie's death, the reports' major concern is the work of the Child Welfare Centre and the development of the public health organization with which the Institute was becoming involved. ${ }^{58}$

There are a number of reasons for this shift of activity. Firstly, Mackenzie, whose interests were primarily on the physiology of symptoms, had gone and the GPs did not have the expertise to follow this up. Secondly, after 1925, the GPs were no longer being paid and were less able to give time to the work of the Institute. As a result, non-GPs had largely taken over. Dr A Maitland Ramsay, a retired ophthalmologist, was appointed Director and the only other doctors who had time to give to the Institute were those who were paid as medical officers in the town and were involved in the public health work. Thirdly, funding was no longer coming from national funding bodies such as the Carnegie Trust and the MRC.

Table 1

Income of the Institute

\begin{tabular}{|c|c|}
\hline Year & Income \\
\hline 1923 & $401116 s \quad 2 d$ \\
\hline 1928 & $226113 s \quad 3 d$ \\
\hline 1933 & $122316 s 11 d$ \\
\hline 1941 & $776 \quad$ ls $1 \mathrm{~d}$ \\
\hline
\end{tabular}

Most of the Institute's diminishing funding in the later 1920s and 1930s (see table) came in the form of small donations from local organizations such as the local ladies' putting club and the St Andrews' pipe band. ${ }^{59}$ Such organizations were more likely to part with their money if it was going towards a public health set-up of value to the local community. Mackenzie's vision of a nationally funded research institute producing work of importance to medicine as a whole, did not survive him. The Institute eventually closed its doors in 1944.

${ }^{57}$ PRO FD 1/572, Dr Thomson (of MRC) to Professor Macwilliam (Dundee), 10 Jan. 1927.

\footnotetext{
${ }^{58}$ Annual reports of the Clinical Institute, op. cit., note 56 above.

${ }^{59}$ Ibid.
} 


\section{Jane Macnaughton}

The first five years of the Institute's existence were, without doubt, the most fruitful. A system of record-taking was established and records were being kept and added to on a regular basis; investigations into the diseases of children were being supported by the MRC; and discussions amongst the medical staff led to the development of Mackenzie's theories about the physiology of symptoms. ${ }^{60}$ The work of this time was disseminated in the form of three volumes of reports, numerous articles in the British Medical Journal and the Lancet, and in Mackenzie's book, The basis of vital activity. ${ }^{61}$ Most of this output was, however, a reworking by Mackenzie of previous ideas or cases and did not add substantially to medical knowledge at the time.

The most striking aspect of the Institute, however, was that it was a research organization led by GPs working in collaboration. Mackenzie's Institute had much in common with the kinds of research organizations associated with other emerging clinical specialties at the time. One example was Thomas Lewis's Department of Clinical Research at University College Hospital. Lewis, who was physician in charge of the cardiographic department at $\mathrm{UCH}$, was a protégé of Mackenzie and this department became the first clinical research unit to be funded by the MRC in 1919. ${ }^{62}$ The Institute at St Andrews was similar in that it involved a group of medical staff in the same clinical area working together to do research; the staff had access to laboratory facilities and links with university scientists; and it had MRC and other national funding. Mackenzie's Institute, however, did not survive in this form. Why was this?

\section{The Institute's Failure and its Significance}

\section{Failure}

A useful schema has been devised by J B Morrell for assessing the success and failure of research schools and I will base my analysis on this. ${ }^{63}$ Morrell's ideas were applied to a comparison of two university based research laboratories in chemistry, those of Justus von Liebig in Geissen and Thomas Thomson in Glasgow, but, as Geison suggests, Morrell's principles can be converted into a useful checklist for

\footnotetext{
${ }^{60}$ Mackenzie's original ideas about the physiology of symptoms were expounded in his book, Symptoms and their interpretation, London, Shaw and Sons, 1909.

${ }^{61}$ The third and final volume of Reports of the St Andrews Institute was published in 1926 (London, Humphrey Milford and Oxford University Press), and although the eighth annual report suggests that a fourth volume was in preparation, it was never published. The rate of publication fell off dramatically after Mackenzie's death. Mackenzie published a series in the Lancet on 'The principles of symptomatology: an introduction to a new outlook in medicine' in an attempt to gain recognition for his theory of
}

disturbed reflexes: Lancet, 1923, ii: 963-8, 1020-4, 1069-74.

${ }^{62}$ Lawrence, op. cit., note 2 above, p. 29. For an account of Mackenzie's significance in Lewis's career see Arthur Hollman, Sir Thomas Lewis: pioneer cardiologist and clinical scientist, London, Springer, 1997, pp. 21-2.

${ }^{63}$ J B Morrell, 'The chemist breeders: the research schools of Liebig and Thomas Thomson', Ambix, 1972, 19: 1-46. Gerald L Geison developed Morrell's idea into a checklist in his later article, 'Scientific change, emerging specialties and research schools', Hist. Sci., 1981, 19: $20-40$, p. 26. 


\section{The St Andrews Institute for Clinical Research}

analysing the Institute as a research school, although it was not a laboratory based institution.

The first principle on which the success of a research school was based, in this schema, was the reputation and charisma of the director. This was important in that it would draw ambitious students to the school and would also help to attract funding. At the time he set up the Institute, Mackenzie was at the end of his career and his health and intellectual powers were waning. Although his reputation enabled him to recruit GP colleagues to work with him, to those of real power and influence in medicine, his ideas were becoming outmoded and indeed ridiculed. ${ }^{64}$ The second main principle concerns manpower. Mackenzie had chosen to site the Institute in a rather isolated place and, although there were reasons for doing this, it was unlikely that as many doctors would be attracted to work with him there as would if it had been sited in a bigger centre. St Andrews had a small number of GPs, most of whom appeared keen to be involved, but this situation could change, and did when funding for salaries became impossible.

Morrell suggests, thirdly, that relatively simple but fast and reliable experimental techniques were essential for the success of a research school. This ensured that not only brilliant but more ordinary students could work and publish but it also meant that the school could succeed in quickly cornering the publishing market in the field it had made its own. It was clear, however, that from the outset Mackenzie's research plan needed long-term commitment. Most diseases did not develop speedily from earliest signs to full-blown pathology and his view was that the value of the work carried out in the Institute would not become clear for up to thirty years. ${ }^{65}$ In addition, the Institute had set itself aims that were too various and too ambitious and the small staff tried to tackle them all at once. This meant that hard won finances were spread thinly and the Institute was unwilling to sacrifice one aspect of the work to help another. ${ }^{66}$

A fourth criterion for success was that the school should have easy access to publishing opportunities. It would be even better if the director, or his friends, had control over a major journal in the field enabling the school to publicize its results and consolidate its hold over a particular area of study. Here again, Mackenzie's waning reputation was against him. A disagreement between him and his former protégé, Thomas Lewis, illustrates the point. In 1921 Mackenzie submitted a paper (the first of an intended series) to Lewis, who was at that time the editor of the journal Heart:

I have been intending to send you several contributions for Heart as I am going over my old angina pectoris cases and finding a wonderful storehouse of material. We have however, been

\footnotetext{
${ }^{64}$ PRO FD 1/571, H Head to W Fletcher, 19 July 1921.

${ }^{65}$ EUL MS Gen. 1980, box 4: 'Papers from the weekly staff meetings', No. 1, May 1933.

${ }^{66}$ EUL MS Gen. 1980, box 1: W Mackenzie to F Mackenzie, 26 April 1941. Sir William
}

\begin{abstract}
Mackenzie (Mackenzie's brother, by this time Lord Amulree) reported to Frances Mackenzie (Mackenzie's widow) that the Council of the Institute were unwilling to give up laboratory and $\mathrm{X}$-ray facilities for the sake of focusing work on the records.
\end{abstract}




\section{Jane Macnaughton}

on the hunt after our disturbed reflexes, and we are beginning to apply them in practice, and I send you the first attempt in that way. ${ }^{67}$

Lewis rejected the paper, disagreeing with Mackenzie's contention that digitalis acted on the vagus nerve and with his interpretation of the idea of the reflex arc. ${ }^{68}$ Mackenzie responded furiously, accusing Lewis of having "lost [his] receptivity to new ideas". He felt that he was on the brink of uncovering a new theory and was being thwarted in trying to get his ideas published:

History has a way of repeating itself. It is just over 30 years since I had my contributions rejected by the Editors of the Lancet and the B.M.J. The papers were the first on irregular hearts, and the discovery of cutaneous hyperalgesis-both the beginning of new methods. Now my first contribution illustrating the application of a new theory is rejected! ${ }^{69}$

In fact, as I have indicated, his methods and ideas were out of step with the prevailing thought in physiology at the time, and his failure to publish or be invited to speak at high profile scientific meetings was proof of this.

The fifth of Morrell's prerequisites concerns institutional support and funding. This problem was fundamental to the Institute's failure and I will focus the remainder of this section on it. The funding issue, however, must be seen in the light of the above problems: the credibility and reliability of the staff; the difficulty of getting published; the complex and long-term tasks the Institute had set itself; but most of all, with the failing power and reputation of the Director himself. Mackenzie was in many ways a paradoxical figure in the medical world of the early twentieth century and did not fit into any of the prevailing models for successful men of medicine that existed at that time.

He was successful in the short term at getting funding but was clearly anxious about the future support and intellectual leadership of the Institute. He had hoped that the MRC would take the Institute over, but this was not to be. Mackenzie had always been regarded as an outsider in the London scene he had entered in 1907 and his ideas did not now find favour amongst those with influence.

The London medical world that Mackenzie entered when he came south from Burnley in 1907 was divided, and general practitioners played no influential part in it. One group with power was what Christopher Lawrence has called the "patrician" or élite doctors of the Royal Colleges. ${ }^{70}$ The gentlemen physicians were clinical generalists whose knowledge-base depended on their clinical experience. These "giants", as Mackenzie's biographer MacNair Wilson called them, controlled appointments to the important consultant posts at the London teaching hospitals and had large private practices in the Harley Street area. ${ }^{71}$ They regarded the

\footnotetext{
${ }^{67}$ Sir Thomas Lewis papers, Archives and Manuscripts, Wellcome Library for the History and Understanding of Medicine (Wellcome), PP/ Lew/A.1/460-483, J Mackenzie to T Lewis, 3 Feb. 1921.

${ }^{68}$ Wellcome, PP/Lew/A.1/460-483, T Lewis to

J Mackenzie, 5 Feb. 1921.

${ }^{69}$ Wellcome, PP/Lew/A.1/460-483, J

Mackenzie to T Lewis, 15 Feb. 1921.
} 


\section{The St Andrews Institute for Clinical Research}

"incommunicable knowledge" of clinical experience as the highest medical good. ${ }^{72}$ They felt that laboratory sciences, particularly physiology, were too prominent in the medical curriculum, and revered morbid anatomy as the major medical science. Anatomy, like clinical medicine, was at that time based more on the skills of observation than, like physiology, on experimentation. Technological expertise and the use of gadgetry, such as Mackenzie's polygraph, did not interest these physicians and they cultivated the ability to make a diagnosis with minimal handling of instruments or, even, of the patient himself. ${ }^{73}$

In addition, there was another group of clinicians in hospital practice who were increasingly specializing in a single category of diseases. Those interested primarily in diseases of the heart or the nervous system relied on the work of laboratory science, mainly in physiology, for the progression of new knowledge in their specialist area but maintained that the lab should remain subservient to clinical observation and skill at the bedside. ${ }^{74}$ Other clinical specialisms were also under development, such as that of orthopaedics. This emerging specialty did not rely on technological or scientific advances but on improvements in clinical skill keeping pace with developments both in hospital and public health practice. ${ }^{75}$ So within the developing clinical specialties there was a further split between those clinicians whose specialty relied on developments in laboratory science and those whose knowledge base relied still on clinical skill and understanding. Both of these groups in the emerging specialties, however, still held that the sciences should be subservient to clinical observation. The approach of the natural historian rather than the experimental scientist still held sway in clinical medicine.

By contrast, laboratory scientists were wielding increasing influence in medicine. The highest status laboratory science at the time was physiology, associated with such names as Sir Michael Foster and Sir Charles Sherrington. These men were carrying out experiments on live animals and learning about the body in its active state, rather than, as with anatomy, in death. This meant that concepts of the working of the human body in health and sickness were developing and were contributing to the knowledge base of two of the main rising clinical specialties, cardiology and neurology. The importance of experimental physiology in clinical medicine was supported by the MRC through the interest of Walter Fletcher, its first secretary. Fletcher, like Foster, Roy and Sherrington, was a Cambridge educated physiologist. In his view, the work of scientists in the laboratory had brought about the greatest advances in medical care in the later nineteenth and early twentieth century:

\footnotetext{
${ }^{72}$ Lawrence, op. cit., note 70 above.

${ }^{73}$ Lawrence, op. cit., note 2 above, p. 9.

${ }^{74}$ Christopher Lawrence,. "A tale of two sciences: bedside and bench in twentieth-century Britain', Med. Hist., 1999, 43: 421-49, p. 421. (Most of the discussion in this section is based on the work of Lawrence in this field.)
}

\footnotetext{
${ }^{75}$ Roger Cooter, Surgery and society in peace and war: orthopaedics and the organization of modern medicine, 1880-1948, Basingstoke, Macmillan in association with the Centre for the History of Science, Technology and Medicine, University of Manchester, 1993, p. 5 .
} 


\section{Jane Macnaughton}

... through the past generation it has been his medical and non-medical colleagues in the scientific laboratory who have been putting into the physician's hands new weapons of precision, in the forging of which he has played little part himself and the mode of action of which he has to take largely on trust. ${ }^{76}$

The article from which this passage is taken was entitled 'Medical research: the tree and the fruit', published in the British Medical Journal in 1929. The "tree" represented the work of laboratory scientists and the "fruit" the practical results of this work in clinical medicine. In this article, Fletcher called for greater attention to be paid to the cultivation of this tree: in other words, he argued for improvements in recruitment, pay and status for basic scientists so that they should not be lured away from this work by what he called the "rival and powerful attraction of medical practice". Many workers in sciences such as anatomy, clinical chemistry, and in his own field, physiology, were medically qualified, and it was his belief that once they entered medical practice, they abandoned any pretensions to serious scientific research.

Fletcher's view is to be contrasted with that of Thomas Lewis, writing in the British Medical Journal in 1930. In his article, Lewis attempted to argue that there was in fact a science of clinical medicine and that it was inextricably linked with specialist rather than generalist medical practice. ${ }^{77} \mathrm{He}$ gave an account of the past of clinical research, saying that it had until recent times been carried out by men who made their living from medical practice but who had used their observations of the spontaneous manifestations of disease to draw conclusions about disease. The new era, said Lewis, must move on from observation to clinical experimentation by men who were specifically trained and had the time for this work:

It is abundantly clear that present progress in clinical medicine is less and less due to observing what chances to happen in beds filled by the routine demands of unselected sick people and of teaching, and more and more attributable to intensive study of selected cases in which manifestations are deliberately sought or actually provoked, or upon which new and often highly technical methods are employed, which are derived from prolonged and searching studies in laboratories. It is equally clear that successful research work in medicine is becoming more and more difficult for the man engaged in practice to prosecute; it is becoming more and more the province of men who train themselves in technical methods of work and in suitable habits of thought. ${ }^{78}$

Just as Fletcher called for support and recognition for basic scientists involved in medically relevant research, Lewis called for support for training posts in clinical research. Lewis had been a pupil of Mackenzie and paid tribute to his work in this article. However, it was Lewis's view that clinical research had moved on from a reliance on the methods of observation by practising clinical generalists to that of experimentation by doctors trained in clinical science. ${ }^{79}$

\footnotetext{
${ }^{76}$ Sir Walter Fletcher, 'Medical research: the tree and the fruit', Br. med. J., 1929; ii: 993-6, p. 994.

${ }^{77}$ Sir Thomas Lewis, 'Observations on research in medicine: its position and its needs', Br. med. J., 1930, i: 479-83. Christopher Booth gives an account of this discussion in his chapter
}

entitled 'Clinical research', in Austoker and Bryder (eds), op. cit., note 24 above, pp. 211-14.

${ }^{78}$ Lewis, op. cit., note 77 above, p. 481.

${ }^{79}$ Wellcome, PP/Lew/A.1/460-483. Correspondence between J Mackenzie and T Lewis, Feb. to March 1921. 


\section{The St Andrews Institute for Clinical Research}

\section{The Mackenzie Paradox}

Mackenzie was a paradoxical figure in this context. ${ }^{80}$ He regarded himself as a general physician and would therefore seem to have been allied with the élite doctors of the Royal Colleges. However, he would have been regarded with some suspicion by these "giants" when he moved south to London in 1907 because of his GP origins, despite his association with the developing specialty of cardiology and his reputation as inventor of the polygraph. Mackenzie's work in cardiology was based on a wide reading of experimental physiology and his conceptualization of the heart was of a dynamic organ not based wholly on its gross anatomy of ventricles and valves. ${ }^{81} \mathrm{He}$ might, therefore, be regarded as in tune with the approach of the clinical specialists or even of the laboratory scientists. But Mackenzie was neither a hospital generalist or specialist, nor was he a laboratory scientist, for all his reverence for the science of physiology. He was a general practitioner and regarded his "specialty" as the only one in medicine which had the skills and opportunity to carry out the true aim of medicine. He wrote of specialists in his book The future of medicine:

His [the specialist's] methods are no doubt of great value in detecting disease after it has advanced so far as to damage the tissues, but the aim of medicine being to prevent and cure disease, he does not help to find out the disease before it has produced damage. It is this extraordinary limitation of outlook which retards the progress of medicine. ${ }^{82}$

Laboratory researchers, in Mackenzie's view, had a similarly limited outlook. He regarded their work as "haphazard" in that it was not focused and directed towards adding to the sum of practical knowledge by a clinical observer:

I want this pursuit to be conducted in a systematic manner, and this can be done by the laboratory worker finding out the mechanism of these signs which the observer perceives by the untrained senses, so that when a doctor sees a patient he can recognise not only the sign but understand how it comes there. The observer feels an irregular pulse-the laboratory worker can explain to him its nature and how it differs from other irregularities $\ldots{ }^{83}$

Walter Fletcher, in his correspondence with Mackenzie in the early 1920s, clearly shared this view that laboratory researchers and clinicians should work more closely together, but felt that Mackenzie's rather dismissive approach to laboratory work was damaging. In a very revealing passage, he accuses Mackenzie of treating scientists in the same way as did the old-fashioned patricians of the Royal Colleges:

You also want to get them together, but I rather think your tactics are wrong; you should chaff the laboratory workers not for being laboratory workers but for keeping away from the bedside. After all, as you know, it is the clinical physicians of the old type who have held the laboratory at arms length, or at the most given it an intolerable patronage. You mean, I think, to do just the opposite, but you and your henchmen in the press are giving now a general impression of an attitude towards scientific work similar in effect to that held by the "gold headed canes". ${ }^{84}$

${ }^{80}$ Osborne, op. cit., note 11 above, p. 527.

${ }^{81}$ Lawrence, op. cit., note 2 above, p. 14-15.

${ }^{82}$ Mackenzie, op. cit., note 3 above, p. 45.

${ }^{83}$ PRO FD $1 / 571$, J Mackenzie to W Fletcher, 9 Aug. 1920.

\footnotetext{
${ }^{84}$ Ibid., W Fletcher to J Mackenzie, 30 July 1920. Mackenzie's "henchmen in the press" refers to the support given to his views by his biographer, MacNair Wilson in The Times.
} 


\section{Jane Macnaughton}

Fletcher's forthright accusation suggests a degree of frustration with Mackenzie, with whose motives he agreed but whose means of achieving results he regarded as counter-productive. He was in fact correct that Mackenzie tended to the "gold headed cane" view of medicine as a clinical generalist who wished to keep laboratory science subservient to the experience of clinical practice by the bedside. As he got older, Mackenzie stood by his increasingly obscure physiological theories with the stubbornness of one who felt that he had more right as a practising doctor to theorize about the mechanisms of illness than those who spent all their time in laboratories. There is evidence that Mackenzie's personality was becoming increasingly difficult in his later years. The German cardiologist, Karl Wenckebach, commented after visiting him that "he has ... become very opinionated and I found it difficult to discuss some matters with him". ${ }^{85}$ Sir Henry Head also said of him: "I cannot see how it is possible to argue with so egocentric a person"; and George Newman baulked at the idea of Mackenzie chairing a Ministry of Health committee on records because he found him tedious and boring. ${ }^{86}$ It is clear from these comments, and also from Mackenzie's rather forthright style in correspondence with other funding bodies, such as the Trustees of the Carnegie UK Trust, that he did not strive to endear himself to those who held the purse strings of funding or who were influential in the profession. ${ }^{87} \mathrm{He}$ regarded himself as playing a "lone hand" in medicine and, as far as the London context was concerned, this was true. ${ }^{88}$ Mackenzie's approach could be seen as more akin to that of medical colleagues in the Scottish universities where the divisions between generalist clinicians, specialists, and laboratory scientists were not so acute and clinicians retained control over laboratory research. ${ }^{89}$

\section{Achievements of the Institute}

Mackenzie's aim of establishing a permanent Institute for research work in general practice failed. It failed partly because he did not live long enough to see it firmly established, and partly because his views were not in tune with those that were beginning to prevail in medical research at the time. It failed also because it simply did not produce enough work which contributed positively to the mainstream developments of medical knowledge at the time. Despite this, the work that was done there had three important practical outcomes. Firstly, the Institute GPs along with Mackenzie developed a system for taking records in general practice which was influential in directing national policy. The memorandum on record taking written by Mackenzie and his colleagues was incorporated into a report by Sir Humphry Rolleston, who was Chair of a committee on the subject of record keeping at the

\footnotetext{
${ }^{85}$ EUL MS Gen. 1980, box 5: Recollections of Sir James Mackenzie sent to Alex Mair (Mackenzie's later biographer).

${ }^{86}$ PRO FD1/571, H Head to W Fletcher, 19 July 1921. The view of Newman is reported in Honigsbaum, op. cit., note 19 above, p. 95.

${ }^{87}$ EUL MS 1980, box 7: J Mackenzie to Miss Haldane (secretary to a trustee of the Carnegie
}

UK Trust), 3 July 1922. Mackenzie writes threateningly: "If we fail, as I expect we will, then it will be on record that the CUK Trust refused to help a scheme which came within their purview."

${ }^{88}$ Wellcome, PP/Lew/A.1/460-483, J

Mackenzie to T Lewis, 19 Jan. 1924.

${ }^{89}$ Smith and Nicolson, op. cit., note 54 above. 


\section{The St Andrews Institute for Clinical Research}

Ministry of Health in $1920 .^{90}$ The resultant Rolleston Report provided direction for the system of inspections of panel doctors' medical records initiated after 1921. ${ }^{91}$ Secondly, the local community in St Andrews benefited from the provision of child and maternity welfare services established by the Institute doctors. Thirdly, the records collected systematically by the staff over the years of the Institute's existence are now in use by the Department of Public Health at the University of Dundee. ${ }^{92}$ This department has been following up these patients and has managed to trace 61 per cent of the 1076 children whose records are still in existence. The main focus of the research has been to study the relationship between respiratory illness in childhood and health in late adulthood-in much the same way as Mackenzie himself would have envisaged his records being used. ${ }^{93}$

\section{Significance of the Institute for GP Research}

Mackenzie's reputation as the father of research in general practice is based mainly on his lone work as a GP in Burnley. But is this a correct analysis? His achievements in Burnley are significant because they showed that it was possible for a humble GP to contribute to the sum of specialist knowledge and to scale the heights of consultant greatness. What is important for GP research, however, is how he did this: by a systematic study and careful recording of the symptoms and signs of his own patient population. He carried this system to new heights at St Andrews, and even more significantly, brought other GPs in to collaborate with him and to learn to apply these same research methods in their own practices.

Mackenzie insisted that GPs had a unique role in the health of patients which was not just a question of identifying serious illness and sending it on to a more qualified person. GPs had the privilege of continual contact with patients over years, and their skills were those of clinical observation. Mackenzie believed that these opportunities and skills could be put to good use in research. He saw this kind of research as of paramount importance in order to uncover the epidemic of undiagnosed disease that GPs and other doctors dealt with daily. ${ }^{94} \mathrm{He}$ felt that the rise of the specialist had skewed research away from this line to the detriment of the health of the majority of people. Most of all, Mackenzie kept his eye on the main object of

\footnotetext{
${ }^{90}$ PRO FD 1/571, 'Memorandum on some of the medical aspects of work under the National Health Insurance Act' by Sir James Mackenzie and the Staff of the St Andrews Institute for Clinical Research, 1919. Honigsbaum's book gives an account of Rolleston's committee, op. cit., note 19 above, p. 97.

${ }_{91}$ Honigsbaum, op .cit., note 19 above, p. 96.

92 This study, called the 'Mackenzie Record Study', is ongoing under the direction of Professor Charles du V Florey at the Department of Epidemiology and Public Health at the University of Dundee.

${ }^{93} \mathrm{~A}$ number of articles have been published on this work, the most recent of which is S O
}

Shaheen, J A C Sterne, J S Tucker and C du V Florey, 'Birth weight, childhood lower respiratory tract infection and adult lung function', Thorax, 1998, 53: 549-53.

${ }_{94}$ In the Institute's first annual report, Mackenzie noted that the results of their preliminary enquiry into "The present state of medical knowledge regarding the diseases common among the people" (Reports, note 56 above, vol. I, pp. 30-48) showed that over 90 per cent of cases met with in general practice were undiagnosable. 


\section{Jane Macnaughton}

research - the better care of the patient. Prevention was better than cure, and if cure was not possible, the patient needed to know what the likely outcome and time scale of the illness would be. These were the questions he had faced when he began as a GP in Burnley, and his shame at being unable to answer them was the spur to his extraordinary rise from obscurity to being the most revered general practitioner of the century.

Although the James Mackenzie Institute for Clinical Research closed its doors in 1944 it was not a failure. It left behind a group of records which is being put to good use today. More significantly, it must be seen as the first step on the way to the establishment of general practice as a specialty with a unique clinical and research role. It was some years before the second step was taken, but general practice was on its way. 